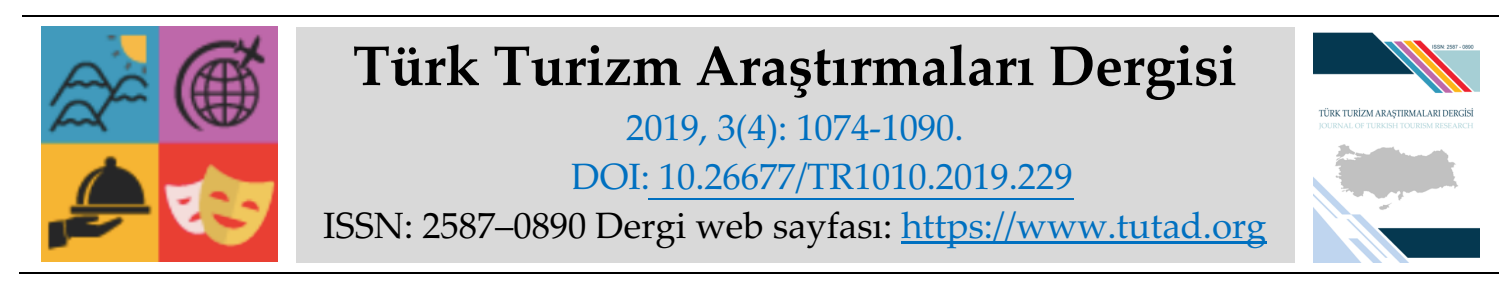

ARASTIRMA MAKALESI

\title{
Festival Turizminin Ekonomik Kalkınmaya Etkisi: Silifke Uluslararası Müzik ve Folklor Festivali
}

Dr. Öğr. Üyesi Cemil SÜSLÜ, İskenderun Teknik Üniversitesi, Turizm Fakültesi, Hatay, e-posta: cemil.suslu@iste.edu.tr

ORCID: https://orcid.org/0000-0003-4164-1552

Dr. Öğr. Üyesi Gamze ERYILMAZ, İskenderun Teknik Üniversitesi, Turizm Fakültesi, Hatay, eposta: gamze.eryllmaz@iste.edu.tr

ORCID: https://orcid.org/0000-0003-0588-8021

Elif DEMIR İskenderun Teknik Üniversitesi, Sosyal Bilimler Enstitüsü, Hatay, e-posta: edemir.sbe17@iste.edu.tr

ORCID: https://orcid.org/0000-0003-2314-1300

Öz

Çalışmada destinasyonun turizm bazında bölgesel kalkınmada etkin olup olmadığı festival turizmi üzerinden ölçülmeye çalışılmıştır. Çalışma alanı olarak Mersin'in Silifke ilçesi belirlenmiştir. Silifke' de her yıl düzenlenen Uluslararası Müzik ve Folklor Festivali ise çalışmanın ana temasını oluşturmaktadır. Festival turizmin bölgesel kalkınmaya katkılarını tespit etmek amacıyla 14 sorudan oluşan açık uçlu soru formu hazırlanmıştır. Araştırma verileri 11 katılımcıdan (İşletme sahipleri, Belediye Başkanı, Kaymakam vb.) yüz yüze görüşmelerle toplanmıştır. Elde edilen verilere içerik analizi uygulanmıştır. Elde edilen bulgulardan hareketle bölgede festival turizmine yönelik ilginin fazla olduğu ancak reklam, tanıtım, pazarlama faaliyetlerinin daha etkin hale getirilmesi gibi birtakım sonuçlara ulaşılmıştır.

Anahtar Kelimeler: Ekonomik Kalkınma, İçerik Analizi, Mersin, Silifke.

Makale Gönderme Tarihi: 11.05.2019

Makale Kabul Tarihi: 02.10.2019

\section{Önerilen Atıf:}

Süslü, C., Eryılmaz, G. ve Demir, E. (2019). Festival Turizminin Ekonomik Kalkınmaya Etkisi: Silifke Uluslararası Müzik ve Folklor Festivali, Türk Turizm Araştırmaları Dergisi, 3(4): 1074-1090. (c) 2019 Türk Turizm Araştırmaları Dergisi. 


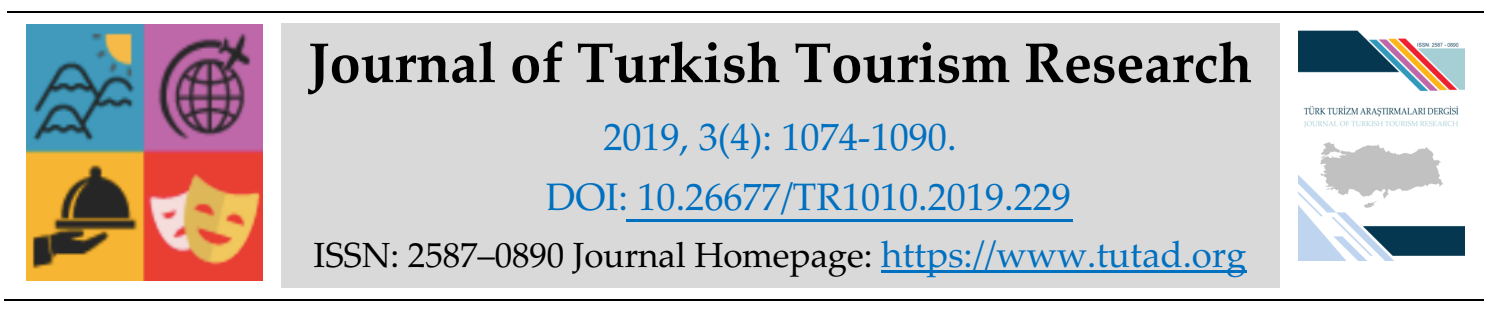

\title{
$\underline{\text { RESEARCH PAPER }}$
}

\section{Economic Development Effect of Festival Tourism: Silifke International Music and Folklore Festival}

Assistant Prof. Dr. Cemil SÜSLÜ, İskenderun Teknik University, Faculty of Tourism, Hatay, email: cemil.suslu@iste.edu.tr ORCID: https://orcid.org/0000-0003-4164-1552

Assistant Prof. Dr. Gamze ERYILMAZ, İskenderun Teknik University, Faculty of Tourism, Hatay, e-mail: gamze.eryılmaz@iste.edu.tr

ORCID: https://orcid.org/0000-0003-0588-8021

Elif DEMİR İskenderun Teknik University, Social Sciences Institute, Hatay, e-mail: edemir.sbe17@iste.edu.tr

ORCID: https://orcid.org/0000-0003-2314-1300

\begin{abstract}
In this study, it has been tried to measure whether the destination is effective on the basis of tourism in regional development through festival tourism. The Silifke district of Mersin was determined as the study area. The International Music and Folklore Festival organized in Silifke every year constitutes the main theme of the study. An open-ended questionnaire consisting of 14 questions was prepared in order to determine the contribution of festival tourism to regional development. The survey data were collected from 11 participants (Business owners, Mayor, District Governor etc.) by face-to-face interviews. Content analysis was performed on the obtained data. Based on the findings, it was found that the interest for festival tourism in the region was high but the advertisement, promotion and marketing activities should be turned into more active.
\end{abstract}

Keywords: Economic Development, Content Analysis, Mersin, Silifke.

Received: 11.05 .2019

Accepted: 02.10.2019

\section{Suggested Citation:}

Süslü, C., Eryılmaz, G. and Demir, E. (2019). Economic Development Effect of Festival Tourism: Silifke International Music and Folklore Festival, Journal of Turkish Tourism Research, 3(4): 10741090.

(c) 2019 Türk Turizm Araştırmaları Dergisi. 


\section{Gíriş}

Turizm sürekli olarak hayat sürdürülen yer dişında bir günden az olmayan ve gelir elde etme amacı gütmeden yapılan seyahat ile bu kısa dönemli yolculuklar esnasında yapılan tüm etkinliklerdir (Güner, 2018: 3). Turizm farklı amaçlarla gerçekleştirilebilecek bir faaliyettir (Ünlüönen vd., 2011: 21). Günümüzde turizm, üretimin artması, istihdam oluşturması, döviz gelirinin sağlanması, gelir dağılımını iyi hale getirmesi gibi ekonomik etkilerinin yanı sıra doğal çevrenin ve tarihi dokunun korunması, toplumsal barışa yardım etmesi, gündelik hayata renk katması ve hareketlilik kazandırmasıyla birçok ülke için önem arz eden bir sektördür (Keskin, 2016: 144). Turizm sektörüne, özel olarak tarihi zenginliklere ve doğal güzelliklere sahip olan ülkelerin gelişmesinde çok mühim bir sorumluluk yüklenmektedir. Kalkınmadaki bu görevi nedeniyle birçok ülke, turizm kaynakları sayesinde turistleri etkileme ve daha çok turizm geliri sağlama çabası içine girmektedir. Burada üzerinde durulması gereken konu, ülkelerin sahip olduğu turistik değerlerden yararlanmasıdır. Bu doğrultuda tek bir turizm çeşidine (deniz-kumgüneş vb.) bağlı olmaksızın, farklı türlerin karıştırılarak birlikte yapıldığı ya da alışılan durumun dışına çıkılan turizm çeşitlerinin ön plana çıkarılması ülkelerin önemli üstünlükler elde etmesini sağlayacaktır (Yemenoğlu vd., 2013: 16). Bacasız sanayi olarak da tasvir edilen turizm sektörü özel olarak Türkiye gibi gelişmekte olan ülkelerin ekonomisinde mühim bir yere sahiptir. Turizm olgusu gelirin en alt seviyeye yayılarak dengeli kalkınmanın gelişim göstermesine olanak vermesi sebebiyle bölgesel, ekonomik ve sosyal kalkınma yönünden elzem dinamiklerden biridir (Küçük, 2012: 1). Çukur ve Kızılaslan (2018) tarafından turizmin gelir getirici özelliği ve istihdam yaratma olanağıyla ekonomik olarak kalkınmaya önemli katkısı bulunduğu ileri sürülmektedir. TÜRSAB verileri incelendiğinde 2018 yılında turizm sektörünün ihracattaki payı 167. 967,2 \$ ile $\% 17,5^{\prime}$ tir (TÜRSAB, 2018). Buradan görüleceği üzere turizm sektörünün ülkenin ekonomisine katkısı büyüktür.

Turizmi seyahat edilen süreye, konaklama tesisine, kullanılan ulaşım aracına, turizm olayına katılanların yaş ortalamasına göre çeşitlendirmek mümkündür (Atalay, 2017: 4). Bu doğrultuda alternatif turizm türlerinin ortaya çıkması kaçınılmazdır. Alternatif turizm, günümüze kadar gerçekleşen turizm hareketleri ve turizm etkinliklerinin olumsuz etkilerini yok etmek, turizme kaynak oluşturacak yeni ürünler oluşturmak için kıyı turizmine alternatif olarak geliştirilmiş olan, diğer taraftan da ülkelerin turizme ait kaynaklarını en üst düzeyde kullanarak kazandıkları gelirleri maksimum seviyeye getirmelerine olanak sağlayan turistik faaliyetler olarak tanımlanmaktadır (Bako, 2016: 10-11). Alternatif turizm türleri içerisinde inanç, sağlık, gastronomi, av, mağara, yayla, dağ, nehir ve kültür turizmi yer almaktadır (Aydın, 2017: 20). Bununla birlikte alternatif turizmin doğa, kış, eko, sağlık, termal, eğitim, kongre, dini, spor vb. gibi pek çok turizm faaliyetini de kapsadığı söylenebilir (Arslan, 2018: 24). Alternatif turizm faaliyetlerinin sürdürülebilmesinde önemli bir yere sahip olan festivaller kültür turizminin bir bölümünü oluşturan etkinlik turizmi içerisinde yer almaktadır (Albayrak, 2013: 71). Bu açıdan düşünüldüğünde festival turizmi de alternatif turizm çeşitleri kapsamında değerlendirilebilir. Çukur ve Kizılaslan (2018)'a göre festivaller turizm sezonunu uzatarak gelir elde etmek amaciyla yerel ekonomiye pozitif yarar sağlamakla birlikte, yöredeki işletmeleri yeni yatırımlara yönlendirmekte aynı zamanda yörede üretilen ürünlerin üretilmesinde ve pazarlamasında büyük katkıları da bulunmaktadır. Festivallerin bahsi geçen katkılarından hareketle festivalin yapıldığı bölgeye ekonomik anlamda ne gibi katkılarının olduğu bu çalışma kapsamında merak konusudur.

Dolayısıyla bu çalışmada festival turizminin, festivalin yapıldığı bölgenin ekonomik kalkınmasına olan etkilerinin irdelenmesi amaçlanmaktadır. Çalışmanın amacına yönelik olarak araştırma kapsamında bir hedef bölge belirlenmiştir. Bu doğrultuda hedef bölgenin ileri gelenlerinin (İşletme sahipleri, Belediye Başkanı, Kaymakam vb.) festivalin kalkınmaya etkilerine 
yönelik olan görüşlerini tespit etmek amacıyla bir araştırma tasarımı geliştirilmiştir. Bu bağlamda da bölge turizmin gelişmesinde önemli bir etkisi olan Silifke Uluslararası Müzik ve Folklor Festivali'nin bir araç olarak ekonomik kalkınmadaki öneminin ortaya konulması hedeflenmiştir.

\section{LITERATÜR TARAMASI}

Festivalin tanımı Türk Dil Kurumu (TDK)' na göre belirli bir sanat kolunda oyun ya da filmlerin sergilenmesi ve gösterilmesi sonucunda ödül, derece verilmesiyle organize edilen milli ya da milletlerarası gösteri dizisi; şenliklerdir (TDK, 2019). Festival kavramı literatürde farklı şekillerde tanımlanmaktadır. Festival; dünyada ve Türkiye'de kültürel ve sanatsal etkinlikler, fuarlar, alışveriş, sergiler, spor olayları gibi organize faaliyetlerdir (Mısırlı ve Özdemir, 2018: 420). Festival, yerel toplum tarafından zamanı önceden belirlenmiş, bölgenin sembolü haline gelen, gelenekselleşen ve sürekliliğin sağlanarak toplumun ortak olarak zihninde yer alan etkinlikler olarak tanımlanmaktadır (Erdem ve Mızrak, 2017: 101). Festivaller, bir yörede belli zamanlarda toplumun kendine özgü bir değeri kutlamak ya da bir olay ve kişiyi anmak için gerçekleştirilen kültürel, sanatsal ve sosyal içerikli faaliyetlerdir (Giritlioğlu vd., 2015: 308). Festivalleri genel olarak ifade etmek gerekirse, festivallerin özgün çekiciliği, eğlence ve kutlama ortamlarından uzak, yaşamın sıradanlığından farklı olmalarından kaynaklanmaktadır (Ekin 2011: 20). Toplum içerisinde festivaller, belli bir zamanlamaya sahip (yılda bir defa veya yılda iki defa gibi) topluluk katılımının önemli bir rol oynadığı tematik kutlama özelliğine sahiptir. Bu nedenle ziyaretçiler etkinlik boyunca, turist olarak veya yerli halk olarak festivale katılım göstermektedirler (Karagöz, 2006: 23). Festivallerde bir yöreye ait bilgi birikim tekrar ve yeniden üretilmekte ve ötekinden farklı kılan tarih, kültürel miras ve sosyal yapılar sürdürülmektedir (Kömürcü, 2013: 23). Festivaller, dünya genelinde insanlar arasında olan dostluğu pekiştirdiği gibi aynı zamanda öğrenilen yeni kültürlere ve yaşantılara duyulan merak duygusunu şiddetlendirerek insanları yeni destinasyonlar görmeye özendirmektedir (Çulha, 2008: 1832). Şengül ve Genç, (2017)'ye göre festivaller önem taşıyan toplumsal kutlamalar olmasıyla birlikte mühim bir turizm cazibesi olarak da karşımıza çıkmaktadır. Festival düzenlemeleri turizm etkinlikleri amacıyla destinasyona gelmiş olan katılımcılara destinasyonun sıradan ilerleyişi dışında etkinlik ortaya koyduğu gibi yalnızca festivale katılım amacıyla da yeni turizm talebi oluşumunu sağlamaktadır. Genel olarak festival turizmi, festival dışı katılım sağlayan kişilerin bir festival periyodu sırasında ziyaret ettikleri olguyu ifade eder (Visser, 2005: 156). En genel anlam dâhilinde festivaller, "türlü sebeplerle gerçekleşen kutlamalardır" şeklinde açıklanabilir.

Avrupa'nın birçok kentinde mühim hadiseler haline dönüşen festivallerin yaygın hale gelmesinde ekonomik katkıların sağladığı politikalarda yatmaktadır (Quinn, 2005: 927). Geçmişte gerçekleşen festivaller, gelir elde etme amacı gütmeden yapılmış olsa da; şu anda düzenlenen festivallerin büyük bir çoğunluğu belirli bir kentsel alan ya da bölge için gelir elde etmeye açık bir şekilde odaklanmıştır. Giderek artan bir şekilde, festival turizmi birçok kasaba ve kentin turizm gelişim stratejilerinin önemli bir özelliği haline dönüşerek kentsel gelişim ya da ekonomik gelişim planlamasının bir parçasını oluşturmaktadır (Visser, 2005: 155). Festival ziyaretçileri, destinasyona gelerek yararlandıkları ulaşım hizmetlerine, konaklama işletmelerine, festival süresince yiyecek-içecek işletmelerine ve diğer gereksinim ve ihtiyaçlarını karşılama amacıyla birçok farklı işletmede aldıkları mal ve hizmetlerinin karşılığında maddi bir bedel ödemektedirler. Hem konuklar hem izleyicilerin festivale katılmalarına bağlı olarak gerçekleşen harcamalar bölge için kısa süren ancak katılımcı sayısına bağlı olarak, nispeten yüksek düzeyli gelir olanağı meydana getirmektedir (Özgürel vd., 2015: 115). Gerçekleştirilen festivallerin direkt olarak ekonomik katkılarının yanı sıra reklam ve pazarlama aracı görevi üstlenmesi de önemlidir (Şengül ve Genç, 2017: 81). Festivaller dâhil oldukları destinasyona para akışı sağlıyor olmaları 
nedeni ile birçok medya kuruluşunun dikkatini çekerek festivalle alakalı diğer hizmetlerin talebini arttırmaktadır (Chhabra, 2001: 2). Festivallerin kent markalaşmasındaki rolünün çok büyük olmasının etkisiyle dünya turizm pazarında öne çıkan bir unsurdur (Kargiglioğlu ve Kabacık, 2017: 411). Destinasyon pazarlamasında ve yerel ekonominin kalkındırılmasında yerel festivaller önemli bir rol üstlenmiştir. Yerel festivaller bölgede sezonu yaymak, düşük sezonu hareketlendirmek, imaj oluşturmak, gelenek göreneklerin tanıtılması ve korunması gibi önemli katkılarda bulunmaktadır (Şengül ve Genç, 2016: 81). Dolayısıyla festivaller, turist çeken ve bu yönüyle yerel konaklama işletmeleri için talep oluşturan faaliyetlerdir (Litvin ve Fetter; 2006: 41).

Genel olarak literatür incelendiğinde festival turizmini konu alan ve olumlu- olumsuz etkileri üzerinde duran birçok çalışmanın yer aldığı görülmektedir. Olumlu etkileri açısından dikkate alındığında bu çalışmalar (Quinn, 2006; Rivara vd., 2008; Sullivan ve Jackson, 2010; Ekin, 2011; Yemenoğlu vd., 2013; Kömürcü, 2013; Tayfun ve Arslan, 2013; Özer ve Çavuşoğlu, 2014; Özgürel, vd., 2015; Özkan vd., 2015; Kalkan ve Çulha, 2016; Yıldız ve Polat, 2016; Erdem ve Mizrak, 2017; Cömert ve Çetin, 2017; Bakırcı vd., 2017; Saatçi ve Yalçınkaya, 2018; Ercan, 2018; Çoban ve Süer, 2018; Mısırlı ve Özdemir, 2018), festival turizminin ekonomik, sosyal ve kültürel yönden katkı sağlamasıyla birlikte, halkın ve esnafın kazanç sağlamasında etkin rol aldığı üzerinde durmuşlardır. Bununla birlikte festivalin, gerçekleştiği destinasyonun tanıtımında da etkin rol oynadığını belirtmişlerdir. Festivalin olumlu etkilerinin yanı sıra olumsuz etkileri açısından dikkate alan çalışmalar ise (Yüksek, vd., 2007; Cudny, 2013) festival alanındaki tesislerin yetersiz olduğu durumda ve plansız kullanım söz konusu olduğunda festivalin, gerçekleştiği doğal çevreye zarar verdiği belirtilmektedir. Bunlara ek olarak festivalin, çevre kirliliği, kültürel mirasın yıpranması, alt ve üst yapının zarar görmesi gibi pek çok olumsuz etkilerinin olabileceği üzerinde durulmaktadır (Cudny, 2013).

Olumlu-olumsuz etkilerinin yanı sıra bazı çalışmalarda ise festivale katılan ziyaretçilerin algıları ve memnuniyetleri incelenmiştir (Bilgili vd., 2012; Gül vd., 2013; Akhoondnejad, 2016; Yolal vd., 2016; Yayla, 2017; Kargiglioğlu ve Kabacık, 2017; Saçllı ve Çevik, 2017; Tanford ve Shinyung, 2017; Taştan vd., 2018; Karaca vd., 2018). Bu çalışmalara göre festivale katılan ziyaretçilerin festivalden memnun ayrılmalarının, festivalin devamlılığı, tutulması yani daha fazla talep görmesi ve finansal açıdan katkı sağlayarak sürdürülebilirliğinin devam etmesi açısından önemli olduğu belirtilmektedir.

Festivaller dünya genelinde bölgesel kalkınma stratejileri başlığı altında önemli bir faktör olarak görülmektedir. Turizm amaçlı yapılan festivaller ise bölgeye turist çekmesi, bölge pazarlamasına katkıda bulunması ve turistik çekim merkezlerini harekete geçirmesi bakımından önemli bir rol üstlenmektedir (Saatçi ve Yalçınkaya, 2018: 156-157). Son yıllarda çeşitli ülkelerde ve şehirlerde organize edilen turizm amaçlı etkinlikler, organize edildiği bölge ekonomisine büyük oranda katkılar sağlamaktadır. Festivallerin genellikle ekonomik etkileri üç farklı kaynaktan oluşmaktadır. Bunlar (Karagöz 2006: 42):

- Festivale katılan ziyaretçiler tarafından gerçekleşen harcamalar,

- Festival sebebiyle yapılan yatırım harcamaları,

- Festivalin gerçekleşmesiyle alakalı, organizatörler tarafından yapılan harcamalardır.

Festival sebebiyle yapılan yatırım harcamaları, turistik bölgedeki alt yapının inşa edilmesi ve geliştirilmesi amacıyla yapılan harcamaları içerirken festival harcamaları etkinliklerin düzenlenmesi ile ilgili reklam ve promosyon gideri, personel gideri gibi fonksiyonel harcamaları kapsamaktadır (Sert, 2013: 36). Ayrıca festivalin gerçekleşmesi amacıyla yapılan organizasyonlar; sergi veya konser alanlarının organize edilmesi, resimlerin gösterilmesi amacıyla galerinin hazır hale getirilmesi gibi etkinlikler festivallerde yeni hizmetlerin oluşmasını da beraberinde 
getirmektedir (Atak, 2009: 41). Festivaller sebebiyle ek hizmetlerin oluşması esnasında pek çok kişi ve kurum, yeni mal ve hizmetler oluşturma ve ek para kazanma yoluyla, ekonominin hareketlenmesine olumlu katkıda bulunacaktır (Kömürcü, 2013: 32). Festival süresince yapılan harcamalar destinasyona gelir artışı sağlaması sebebiyle kamunun dikkatini çekmekte ve kamu yatırımlarını doğal olarak bu bölgelere yönlendirmektedir (Özgürel vd., 2015: 115). Bu doğrultuda festival turizmi, sistem pazarlaması ile eşsiz yerel kültür değerlerinin geliştirilmesi ve kullanım aracılığıyla bölgenin turizm gelişimini olumlu etkileyen, alakalı endüstrilerin gelişimini yönlendiren bir turizm çeşididir (Congcong, 2014). Sonuç olarak festival turizmi, turizm pazarında hızlı bir şekilde gelişen bir sektör olup, turizm sezonunu uzatmak, turizmi çeşitlendirmek, turizm talebinin artmasını sağlamak, bölgeye yeni gelir kaynağı oluşturmak, destinasyonların çekiciliğini ve farkındalığını arttırmasına yardımcı olmaktadır (Çoban ve Süer, 2018: 61).

Festival turizmine yönelik farklı açılardan incelenen çalışmalardan hareketle, araştırma tasarımıyla birlikte hem çalışma alanı hem de festivalin yapıldığı bölge açısından düşünüldügünnde Silifke Uluslararası Müzik ve Folklor Festivaline yönelik yapılmış herhangi bir akademik çalışmaya rastlanılmamıştır. Dolayısıyla bu çalışmada, çalışma alanı ve bölgesi olarak Silifke Uluslararası Müzik ve Folklor Festivali ele alınmış ve festivalin ekonomik kalkınmaya etki düzeyini tespit etmeye yönelik nitel bir araştırma tasarımı izlenmiştir.

\section{ARAŞTIRMANIN AMACI}

Bu çalışma, Mersin ilinin Silifke ilçesinde her yıl Mayıs ayında düzenlenmekte olan Silifke Uluslararası Müzik ve Folklor Festivali'nin ekonomik kalkınmaya etkisinin belirlenmesi ve bölgenin sahip olduğu festival turizmi potansiyelinin nasıl turizm sektörüne kazandırabileceğini ortaya çıkarmak amacıyla yapılmıştır. Bu kapsamda "Silifke'de festival turizmi potansiyeli var mı?", eğer varsa "Bu alternatif turizm çeşidinin bölgenin turizm potansiyelinin arttırılmasındaki rolü nedir?", "Festival turizmi bölgesel/ekonomik kalkınmada etkili olabilir mi?" sorularına cevap aramak ve birtakım çözüm önerileri sunmak istenmiştir. Dolayısıyla bu çalışma, araştırma bölgesinin festival turizmi potansiyeli hakkında fikir vermesi, mevcut potansiyelin geliştirilmesi, Silifke turizmine sağlayabileceği faydalarının ortaya konması, Silifke'nin kalkınmasında turizmin etkilerinin belirtilmesi, buna yönelik çözüm önerileri sunması ve literatüre katkı sağlaması açısından önem arz etmektedir.

\section{ARAŞTIRMANIN YÖNTEMI}

Bu çalışma araştırma amacına yönelik olarak nitel araştırma yöntem ve analiz sürecine uygun bir şekilde tasarlanmıştır. Araştırmada yarı yapılandırılmış görüşme tekniği uygulanmıştır. Araştırmanın amaçlarına ulaşabilmek için, açı uçlu yarı yapılandırılmış veri toplama formu kullanılmıştır. Burada amaç, katılımcıların açık uçlu sorulara kendi isteklerine göre öznel olarak cevap vermesine olanak vermektir (Yıldırım ve Şimşek, 2016: 138). Veri toplama formunda öncelikle çalışma ile ilgili bilgilerin verildiği bir paragraf verilmiştir. Sonraki kısımda 14 açık uçlu araştırma sorusu ve katılımcı özelliklerini belirlemeye yönelik cinsiyet ve yaş olmak üzere 2 soru yer almaktadır. Araştırma soruları, Dönmez (2015), Şengel (2015) ve Kılıçoğlu (2018)'nun çalışmalarından derlenmiş ve araştırmanın yapıldığı bölgeye göre uyarlanarak hazırlanmıştır.

Araştırma soruları aşağıdaki gibidir:

1. Silifke' ye yönelik turizm talebini arttırmak için ne gibi faaliyetler yürütülebilir? 
2. Silifke'nin turizm gelişimi açısından sahip olduğu avantajları değerlendirebilir misiniz?

3. Silifke'nin turizm gelişimi açısından sahip olduğu dezavantajları değerlendirebilir misiniz?

4. Silifke'nin ekonomik olarak gelişmesinde ön planda olan gelir kaynakları nelerdir? Turizmin buradaki önemine değinir misiniz?

5. Turistlik değerlerin korunması ve turizm bilincini geliştirmek için Silifke'de mevcut sivil toplum kuruluşu bulunmakta mıdır? Bulunan kuruluşlar yeterli midir?

6. Silifke' ye yönelik festival turizm talebini değerlendirebilir misiniz?

7. Festival turizm talebini arttırmak için ne gibi önerilerde bulunabilirsiniz?

8. Silifke' de bulunan yerel halkın festival turizmine bakış açısı nasıldır?

9. Silifke'de Festival'in bölgesel kalkınmaya muhtemel etkileri hakkında neler düşünüyorsunuz?

10. Festivalin bölgede yarattığ 1 iş istihdamı hakkında ne düşünüyorsunuz?

11. Festivalin bölgeye yönelik sağladığı yatırım artışını nasıl değerlendiriyorsunuz?

12. Festivalin bölgenin fiyatlarına olan etkisini nasıl değerlendirirsiniz?

13. Festival ile birlikte bölgedeki diğer ürünlere (yöresel gidalar, tekstil ürünleri, yöreye özgü eşyalar vs.) olan talep durumunu değerlendirebilir misiniz?

14. Festival turizminin Silifke'nin ekonomik kalkınması açısından yararlarını değerlendirebilir misiniz?

Araştırma soruları kendi içerisinde soru içerikleri bakımından üç farklı kategoride değerlendirilmektedir. 1-5 numaralı sorular bölgenin turizm durumu ile ilgilidir; 6, 7, 8 numaralı sorular, festivalin mevcut durumu ile ilgilidir ve 9-14 numaralı sorular ise bölgesel kalkınma ile ilgili sorulardır. Analiz ve bulgular kısmında kategorilendirme süreci bahsi geçen değerlendirmeler üzerinden yapılmıştır.

Görüşmeler 11-16 Şubat 2019 tarihlerinde yapılmıştır. Tesadüfi olmayan örnekleme yöntemlerinden kasti (kararsal) örnekleme tekniği kullanılarak gerçekleşen görüşmeler, 11 katılımcı ile gerçekleşmiştir. Kasti örnekleme de örneği oluşturan elemanlar araştırmacının araştırma problemlerine cevap bulacağına inandığı kişilerden seçilir (Coşkun vd., 2017: 149). Bu örnekleme tekniğinin amacından hareketle Belediye Başkanı, Kaymakam, Esnaf Odası Başkanı, Kültür Müdürü, Turizm Danışma Memuru ve 6 İşletme Sahibi (2 restoran, 3 pastane, 1 seyahat acentesi) ile görüşülmüştür. Yapılan görüşmeler, 45 dakikalık bir sürede gerçekleşmiştir. Görüşmeye başlamadan hemen önce katılımcılara, bu araştırmanın neden gerçekleştiği ve ne kadar süreceği açılanmıştır.

\section{ARAŞTIRMANIN ANALIZZ VE BULGULARI}

Çalışmada elde edilen verilere nitel veri analizi yöntemlerinden "İçerik Analizi" uygulanmıştır. İçerik analizi katılımcıların görüşlerinin içeriklerini düzenli bir şekilde belirtmek için, gözlem, görüşme, dokümanlar ve mülakat dökümlerinin kayıtlarının karakterize edilerek kararlaştırılması için kullanılan bir tekniktir (Yıldız, 2014: 38). İçerik analizi sürecinde veriler dört aşamada analiz edilir (Yıldırım ve Şimşek, 2016: 243-254). 
1-Verilerin kodlanması; veriler arası bulunan anlamlı bölümlere (bir kelime, bir tümce, bir paragraf) ad verme sürecidir.

2-Temaların bulunması; ilk aşamada oluşan kodlar aracılığıyla verileri, genel seviyede belirtebilen ve kodları belli kategorilerde toplayan temaların belirlenmesi gereklidir. Burada, kodlar arası ortak olan özellikler belirlenmeye çalışılmaktadır. Bu bir bakımdan tematik kodlama işlemidir ve verilen kodlar aracılı̆̆ıyla kategorize edilmesidir.

3-Verilerin kodlara ve temalara göre düzenlenmesi; bu süreçte araştırmacı, ilk iki aşama sonucunda elde ettiği verileri düzenleyeceği bir sistem meydana getirir. Üçüncü aşamada ise araştırmacı, bu sisteme göre elde edilen verileri düzenler ve bu biçimde belirli olgulara bakarak verileri hazırlar ve bu biçimde belli olgulara göre tanımlamak ve yorumlamak mümkündür.

4-Bulguların yorumlanması; detaylı bir biçimde tanımlanmış olan ve sunulan bulguların araştırmacı tarafından yorumlanması ve bazı sonuçların elde edilmesi bu aşamada gerçekleşir. Burada araştırmacı, topladığı verilere anlam kazandırmayı ve bulgular arası ilişkileri izah etmek, sebep-sonuç ilişkileri ortaya koymak, bulgular aracılığıyla birtakım sonuçlar elde etmek ve bu sonuçların önemine ait izahlar yapmak mecburiyetindedir.

Araştırmaya ait veri analizi kısmında öncelikle (1) araştırmaya katılan 11 katılımcının yaş ve cinsiyet gruplarına göre dağılımı oluşturulmuştur. Bu dağılım Tablo 1'de gösterilmektedir. (2) Toplanan verilere daha kolay ulaşabilmek için katılım formları numaralandırılmıştır. (3) İkinci aşamada her katılım formundaki her soru için ayrı olarak sıklık seviyesine göre kendi içerisinde bütünlük oluşturan ifadeler kodlandırılmıştır. Her bir kodu hangi katılımcının ifade ettiğini göstermek için yanına katılımcı numarası belirtilmiştir. (4) Ortak bütünlük oluşturan ifadeler adlandırıldıktan sonra, ortak ifadeler taşıyan kodlar alt kategori olarak belirtilmiştir. Alt kategorilerde kendi içerisinde anlamlı olarak kategorize edilmiştir. (5) Son aşamada ise elde edilen veriler tablolar aracılığıyla anlaşılır bir biçimde tanımlanmış ve yorumlanmıştır.

Tablo 1: Katılımcların Özelliklerinin Belirlenmesi

\begin{tabular}{|l|c|c|c|c|}
\cline { 2 - 5 } \multicolumn{1}{c|}{} & Yaş Aralığı & Katılımclar & F & $\%$ \\
\hline \multirow{4}{*}{ Yaş } & $20-30$ & $\mathrm{~K} 11$ & 1 & 9 \\
\cline { 2 - 5 } & $31-40$ & $\mathrm{~K} 3, \mathrm{~K} 4, \mathrm{~K} 5, \mathrm{~K}, \mathrm{~K} 7, \mathrm{~K} 8$ & 6 & 54 \\
\cline { 2 - 5 } & $41-50$ & $\mathrm{~K} 9, \mathrm{~K} 10$ & 2 & 18 \\
\hline Cinsiyet & $50+$ & $\mathrm{K} 1, \mathrm{~K} 2$ & 2 & 18 \\
\hline
\end{tabular}

Tablo 1'de verilen frekans analizi sonucuna göre araştırmaya katılan katılımcının (\%100) 'ü erkeklerden oluşmaktadır. Katılımcıların yaş aralığı incelendiğinde (\%54)'nün 31-40 yaş arası bireylerden oluştuğu görülmektedir.

Analiz sürecinin sonraki aşamasında 11 katılımcıdan 14 araştırma sorusuna alınan yanıtlardan hareketle, elde edilen verilere içerik analizi uygulanmıştır. Analiz aşamasında14 soru kendi içinde üç kategoride değerlendirilmiştir (Tablo 2, 3 ve 4). Tablolarda görüleceği üzere her bir kategori kendi içinde alt kategorilere ayrılmıştır. Her bir alt kategori, her bir araştırma sorusundan alınan yanıtlar doğrultusunda oluşturulmuştur. Bu nedenle her bir soruya alınan yanıtlardan elde edilen ifadeler, sorulan soruyu içerecek şekilde kendi kategorileri altında değerlendirilmiştir. Bu kategoriler altında da kod olarak etiketlenen ifadeler, frekansı en çok olandan en az frekansa sahip ifadeler şeklinde sıralanmıştır. Sonrasında toplam ifade sayısına ve yüzdelik değerlerine yer verilmiştir. İlk kategori olan Bölgenin Turizm Durumu Tablo 2'de sunulmuştur. 
Tablo 2: Bölgenin Turizm Durumunun Kategorileştirilmesi

\begin{tabular}{|c|c|c|c|c|c|}
\hline Kategori & Alt Kategori & Kod & $\Sigma \mathbf{i}$ & $\begin{array}{l}\Sigma \mathrm{i} \\
(81)\end{array}$ & $\%$ \\
\hline \multirow{22}{*}{ 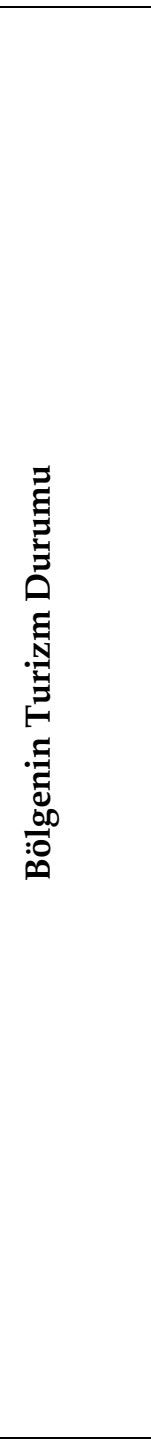 } & \multirow[t]{6}{*}{ Turistik faaliyet istekleri } & $\begin{array}{l}\text { Doğal tarihi ve kültürel } \\
\text { varlıklar tanıtılmalı }\end{array}$ & 5 & \multirow{6}{*}{12} & \multirow{6}{*}{14,8} \\
\hline & & Tesisler yapılmalı & 3 & & \\
\hline & & $\begin{array}{l}\text { Restorasyon çalışmaları ve } \\
\text { çevre düzenlemeleri } \\
\text { yapılmalı }\end{array}$ & 1 & & \\
\hline & & Turizme değer verilmeli & 1 & & \\
\hline & & Eğlence yerleri artırılmalı & 1 & & \\
\hline & & Teşvik verilmeli & 1 & & \\
\hline & \multirow[t]{3}{*}{$\begin{array}{l}\text { Mevcut Turizm } \\
\text { Potansiyeli }\end{array}$} & $\begin{array}{l}\text { Doğal, tarihi, kültürel } \\
\text { destinasyonlara sahip }\end{array}$ & 11 & \multirow{3}{*}{20} & \multirow{3}{*}{24,6} \\
\hline & & İklim & 5 & & \\
\hline & & $\begin{array}{l}\text { Alternatif turizm potansiyeli } \\
\text { var }\end{array}$ & 4 & & \\
\hline & \multirow[t]{8}{*}{$\begin{array}{l}\text { Turizm neden } \\
\text { gelişmiyor? }\end{array}$} & $\begin{array}{l}\text { Tarım ve hayvancılık az da } \\
\text { olsa sanayi sektörünün ön } \\
\text { plana çıması }\end{array}$ & 11 & \multirow{8}{*}{28} & \multirow{8}{*}{334,5} \\
\hline & & Tanitım eksikliği & 4 & & \\
\hline & & Hava alanı eksikliği & 4 & & \\
\hline & & Ulaşım eksikliği & 3 & & \\
\hline & & Nükleer santral & 2 & & \\
\hline & & Tesis yetersizliği & 2 & & \\
\hline & & Siyasi bürokrasi & 1 & & \\
\hline & & Turizm bilinç eksikliği & 1 & & \\
\hline & \multirow{2}{*}{$\begin{array}{l}\text { Turizm sektörünün } \\
\text { durumu }\end{array}$} & Az gelişmiş & 5 & \multirow[b]{2}{*}{10} & \multirow[b]{2}{*}{12,3} \\
\hline & & Gelişmemiş & 5 & & \\
\hline & \multirow{3}{*}{$\begin{array}{l}\text { Turizmi geliştirme } \\
\text { amaçlı sivil toplum } \\
\text { kuruluşu durumu }\end{array}$} & Yetersiz & 6 & \multirow{3}{*}{11} & \multirow{3}{*}{13,5} \\
\hline & & Yeterli & 3 & & \\
\hline & & Bilgim yok & 2 & & \\
\hline
\end{tabular}

Tablo 2' de görüldüğü üzere, bölgenin turizm durumu kategorisi turizm faaliyet istekleri, mevcut turizm potansiyeli, turizm neden gelişmiyor, turizm sektörünün durumu ve turizmi geliştirme amaçlı sivil toplum kuruluşu durumu alt kategorilerinden oluşmuştur. "Bölgenin Turizm Durumu" kategorisinin \%34,5'i "turizm neden gelişmiyor" alt kategorisinden oluşmaktadır. Bununla birlikte "mevcut turizm talebi" alt kategorisinin de $\% 24,6$ olduğu görülmektedir. Bu iki kategori bölgenin turizm açısından durumunu değerlendirmede yüksek bir paya sahipken, $\% 12,3$ ile "turizm sektörünün durumu" alt kategorisinin en düşük paya sahip kategori olduğu görülmektedir.

"Turistik faaliyet istekleri" alt kategorisinde doğal, tarihi, kültürel varlıkların tanıtılması, tesislerin yapılması, restorasyon çalışmaları ve çevre düzenlemeleri yapılmalı, turizme değer verilmeli, eğlence yerleri yapılmalı ve teşvik verilmeli kodları yer almıştır. Katılımcılar çoğunlukla doğal, tarihi, kültürel varlıkların tanıtılması bulgusuna değinmişlerdir. Daha sonra 
ise tesisler yapılmalı bulgusuna değinmişlerdir. Katılımcıların bu bulgulara yönelik ifadeleri aşağıdaki gibi örneklendirilebilir (K=Katılımcı):

K1: “Kültür varlıklarının çevre düzenlemesi yapılmalı, yatak kapasitesi fazla olan tesisler yapılmalı, restorasyon çalışmaları yapılmalıdır."

K2: “.... Ayrıca var olan tarihi ve doğal güzelliklere sahip mekânların tanıtımının en iyi şekilde yapılması gerekmektedir."

İkinci alt kategori olan "mevcut turizm potansiyeli" ise doğal, tarihi, kültürel destinasyonlara sahip olma, iklim ve alternatif turizm potansiyeli kodlarından oluşmuştur. Katılımcılar genel olarak destinasyonlara sahip olması bulgusunu belirtmişlerdir. Bu bulguyu iklim bulgusu takip etmiştir. Katılımcıların bu bulgulara yönelik ifadeleri aşağıdaki gibi örneklendirilebilir:

K3: "Çok fazla tarihi ören yerlerinin olması ve mağaraların fazla bulunması avantaj olarak değerlendirilebilir."

K8: “Deniz ve yayla birbirine çok yakın ve iklim koşulları her türlü (alternatif) turizme müsaittir."

"Turizm neden gelişmiyor" alt kategorisinde tarım ve hayvancılık az da olsa sanayi sektörünün ön plana çıkması, tanıtım eksikliği, hava alanı eksikliği, ulaşım eksikliği, nükleer santral, tesis yetersizliği, siyasi bürokrasiler ve turizm bilinç eksikliği kodları yer almıştır. Katılımcıların çoğunluğu tarım ve hayvancılık az da olsa sanayi sektörünün ön plana çıkması bulgusunu vurgulamışlardır. Bu bulguyu hava alanı ve tanıtım eksikliği takip etmiştir. Katılımcıların bu bulgulara yönelik ifadeleri aşağıdaki gibidir:

K7: "Silifke'nin gelişiminde tarım yani çiftçilik ön plandadır Turizm'in gelişimi sıfırdır."

K2: “Hava alanı ulaşımı açısından sıkıntılı bir bölgedir. Nükleer santral çok yakın tehlike olarak algılanmaktadır. Turizm tesisleri yetersizdir."

Üçüncü alt kategori olan "turizm sektörünün durumu "nu az gelişmiş ve gelişmemiş kodları oluşturmuştur. Katılımcılar turizm sektörünün az gelişmiş olduğu bulgusunu belirtmişlerdir. Katılımcıların bu bulgulara yönelik ifadeleri aşağıdaki gibidir:

K4: "Tesisler az olduğu için ve tanıtım az olduğu için turizm sektörü yetersiz kalıyor."

Son alt kategori olan "turizmi geliştirme amaçlı sivil toplum kuruluşu durumu "nu yetersiz, yeterli, bilgim yok kodlarından oluşmuştur. Katılımcılar turizmi geliştirme amaçlı sivil toplum kuruluşunun yetersiz olduğu bulgusunu belirtmişlerdir. Katılımcıların bu bulgulara yönelik ifadeleri aşağıdaki gibi örneklendirilebilir:

K2: "Çeşitli Doğa dernekleri ve kültür dernekleri bulunmaktadır sayı olarak yeterli fakat nitelik olarak yetersiz olduğunu düşünmekteyim."

K3: “Belediye Kültür Müdürlüğü mevcut ama yeterli değildir.”

Tablo 3'de görüldüğü üzere festivalin mevcut durumu kategorisi beklentiler, katılım durumu, memnuniyet ve tavsiyeler alt kategorilerinden oluşmuştur. "Festivalin mevcut durumu" kategorisinin \%29,'u "katılım durumu ve tavsiyeler" ile \%29'u "festival niteliği iyileştirilmeli" alt kategorilerinden oluşmuştur. Bu iki kategori festivalin mevcut durumunu değerlendirmede yüksek paya sahiptir. Ancak \%19,3 ile "memnuniyet" alt kategorisinin en düşük paya sahip olduğu görülmektedir.

İlk alt kategori olan "beklentiler" kategorisinde eğlence, ekonomik getiri, hava alma, şehir hayatında hareket kodları bulunmaktadır. Katılımcılar festivalden beklentisinin daha çok eğlence 
olduğu bulgusuna değinmişlerdir. Katılımcıların bu bulgulara yönelik ifadeleri aşağıdaki gibi örneklendirilebilir:

Tablo 3: Festivalin Mevcut Durumunun Kategorileştirilmesi

\begin{tabular}{|c|c|c|c|c|c|}
\hline Kategori & Alt Kategori & Kod & $\Sigma \mathbf{i}$ & $\Sigma i(31)$ & $\%$ \\
\hline \multirow{10}{*}{ 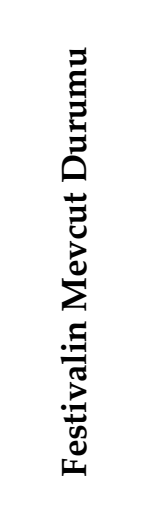 } & \multirow{4}{*}{ Beklentiler } & Eğlence & 3 & \multirow{4}{*}{7} & \multirow{4}{*}{22,5} \\
\hline & & Ekonomik getiri & 2 & & \\
\hline & & Hava alma & 1 & & \\
\hline & & Şehir hayatında hareket & 1 & & \\
\hline & \multirow{2}{*}{$\begin{array}{l}\text { Katılım } \\
\text { durumu }\end{array}$} & Talep fazla & 8 & \multirow{2}{*}{9} & \multirow{2}{*}{29} \\
\hline & & Talep az & 1 & & \\
\hline & Memnuniyet & Olumlu & 6 & 6 & 19,3 \\
\hline & \multirow{3}{*}{ Tavsiyeler } & Reklam ve tanitım & 4 & \multirow{3}{*}{9} & \multirow{3}{*}{29} \\
\hline & & $\begin{array}{l}\text { Festival niteliği } \\
\text { iyileştirilmeli }\end{array}$ & 3 & & \\
\hline & & Kaliteli sanatçılar getirilmeli & 2 & & \\
\hline
\end{tabular}

K4: "Sadece eğlenmek için geliyorlar."

K2: .... “Özellikle esnafların olumlu görüşleri vardır her türlü kent hayatının canlanmasına katkı sağlamaktadır."

K9: "Halk sadece ekonomik açıdan festivali düşünmektedir."

İkinci alt kategori olan "katılım durumu" kategorisinde ise talep fazla ve talep az olmak üzere iki kod yer almaktadır. Katılımcılar festivale talebin fazla olduğunu belirtmişlerdir. Katılımcıların bu bulgulara yönelik ifadeleri aşağıdaki gibi örneklendirilebilir:

K3: “Çok yoğun bir ilgi var. Yerli ve yabancı katılımcılar mevcuttur......”

K5: "Mevcut bir talep var ancak tanıtım yapılmalıdır."

Üçüncü alt kategori olan "memnuniyet" kategorisini olumlu kodu yer almaktadır. Katılımcılar festival ziyaretçilerinin memnuniyetlerinin olumlu olduğu bulgusunu belirtmişlerdir. Katılımcıların bu bulguya yönelik ifadeleri aşağıdaki gibi örneklendirilebilir:

K3: "Festivali çok sevdiklerini ve talep ettiklerini düşünüyorum."

K7: "Yerel halkın Festivali sevdiğini düşünüyorum"

Son alt kategori olan "tavsiye" kategorisinde ise reklam ve tanıtım, festival niteliği iyileştirilmeli, kaliteli sanatçılar getirilmeli kodları yer almaktadır. Katılımcılar festivalin reklam ve tanıtımının yapılması bulgusunu belirtmişlerdir. Ayrıca festival niteliğinin iyileştirilmesi ve kaliteli sanatçların festivale getirilmesi tavsiyelerinde de bulunmuşlardır. Katılımcıların bu bulgulara yönelik ifadeleri aşağıdaki gibi örneklendirilebilir:

K7: “Var ama gelen sanatçıların bazıları tanınmıyor. Daha ünlü sanatçllar getirilirse talep artar.”

K10: “Reklam ve tanıtım yapılmadır. Festival niteliği geliştirilmelidir. Örnek olarak gelen sanatçının kalitesine göre festivale o gün katılım artıyor."

Tablo 4'de görüldüğü üzere bölgesel kalkınma kategorisi iş istihdamı, yatırım artışı, bölgenin fiyatları, yöreye özgü ürünler ve ekonomik kalkınma alt kategorilerinden oluşmuştur. "Bölgesel kalkınma" kategorisinin \%22,2'si ekonomik kalkınma alt kategorisinden oluşmuştur. Bu kategori 
bölgesel kalkınmayı değerlendirmede yüksek paya sahiptir. \%20,3 ile bölgenin fiyatları ve yöreye özgü ürünler alt kategorileri aynı paya sahiptir. Aynı zamanda \%18,5 ile iş istihdamı ve yatırım artışı alt kategorileri en düşük paya sahiptir.

Tablo 4: Bölgesel Kalkınmanın Kategorileştirilmesi

\begin{tabular}{|c|c|c|c|c|c|}
\hline Kategori & Alt Kategori & Kod & $\Sigma \mathbf{i}$ & $\Sigma i(54)$ & $\%$ \\
\hline \multirow{12}{*}{ 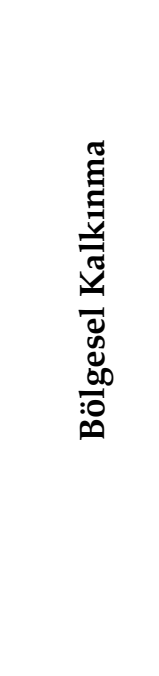 } & \multirow{2}{*}{ İş istihdamı } & Etkisi yok & 6 & \multirow{2}{*}{10} & \multirow{2}{*}{18,5} \\
\hline & & Etkisi var & 4 & & \\
\hline & \multirow{2}{*}{ Yatırım artışı } & Yok & 8 & \multirow{2}{*}{10} & \multirow{2}{*}{18,5} \\
\hline & & Var & 2 & & \\
\hline & \multirow{2}{*}{ Bölgenin fiyatları } & Fiyatlar sabit & 9 & \multirow{2}{*}{11} & \multirow{2}{*}{20,3} \\
\hline & & Bilgim yok & 2 & & \\
\hline & \multirow{2}{*}{ Yöreye özgü ürünler } & Talep Var & 7 & \multirow{2}{*}{11} & \multirow{2}{*}{20,3} \\
\hline & & Talep Yok & 4 & & \\
\hline & \multirow{4}{*}{ Ekonomik kalkınma } & Etkisi Var & 4 & \multirow{4}{*}{12} & \multirow{4}{*}{22,2} \\
\hline & & Etkisi Yok & 4 & & \\
\hline & & $\begin{array}{l}\text { Ekonomide dönemsel } \\
\text { hareketlilik }\end{array}$ & 3 & & \\
\hline & & $\begin{array}{l}\text { Reklam olarak etkisi } \\
\text { var girdisi az }\end{array}$ & 1 & & \\
\hline
\end{tabular}

Illk alt kategori olan "iş istihdamı" kategorisinde etkisi yok ve etkisi var kodları yer almaktadır. Katılımcılar daha çok festivalin iş istihdamına etkisi olmadığı bulgusuna değinmişlerdir. Katılımcıların bu bulgulara yönelik ifadeleri aşağıdaki gibi örneklendirilebilir:

K5: "Bir hafta sürdüğü için iş istihdamı sağlamıyor."

K9: "İş istihdamı yaratmıyor. Sadece o haftayı kurtarmak adına eleman alınıyor."

İkinci alt kategori olan "yatırım artışı" kategorisinde ise var ve yok kodları bulunmaktadır. Katılımcıların çoğunluğu festivalin yatırım artışı sağlamadığı bulgusunu belirtmişlerdir. Katılımcıların bu bulgulara yönelik ifadeleri aşağıdaki gibi örneklendirilebilir:

K10: "Festival dönemlik olduğu için yatırım olmuyor. Sadece dışarıdan insanlar ticaret amacıyla o dönemde bölgeye geliyor."

K8: "Kısa süreli olduğu için sağladığını düşünmüyorum."

Üçüncü alt kategori olan "bölgenin fiyatları" kategorisinde fiyatlar sabit ve fikrim yok kodları yer almaktadır. Katılımcılar daha çok fiyatların sabit kaldığı bulgusunu vurgulamışlardır. Katılımcıların bu bulgulara yönelik ifadeleri aşağıdaki gibi örneklendirilebilir:

K11: "Festival döneminde fiyatlarda artış olmuyor. Sabit fiyat uygulaması vardır."

K2: "Fiyatlar hakkında herhangi bir yorum yapamıorum."

Dördüncü alt kategori olan "yöreye özgü ürünler" kategorisinde talep var ve talep yok olmak üzere iki kod vardır ve katılımcıların çoğunluğu talebin var olduğu bulgusunu belirtmişlerdir. Katılımcıların bu bulgulara yönelik ifadeleri aşağıdaki gibi örneklendirilebilir:

K10: “Yoğurt ya da tarımsal ürünlere (çilek gibi) olan talep artıyor.”

K3: “Bölgeyi öne çıkaran ürünlere çok yoğun talep olmaktadır.” 
Son alt kategori olan "ekonomik kalkınma" kategorisinde ise etkisi var, etkisi yok, ekonomide dönemsel bir hareketlilik, reklam olarak etkisi var girdisi az kodları yer almaktadır. Katılımclardan ekonomik kalkınmaya etkisi olduğu ve etkisi olmadığı bulgusuna eşit miktarda değinmişlerdir. Ayrıca festivalin ekonomide dönemsel bir hareketlilik sağladığı bulgusuna değinenlerde çoğunluktadır. Katılımcıların bu bulgulara yönelik ifadeleri aşağıdaki gibi örneklendirilebilir:

K9: "Hem ekonomik hem de kültürel katkısı var ama yeterli değildir. Artış sağlamıyor sadece hareketlilik katıyor."

K4: "Sadece ekonomide hareketlilik sağlıyor."

K5: “Dönemlik olduğu için etkisi yok sadece hareketlilik katıyor.”

\section{SONUÇ VE ÖNERILER}

$\mathrm{Bu}$ çalışma festival turizminin; yerel yönetimin, turizm ve yiyecek içecek hizmetleri amacıyla faaliyet gösteren işletme sahiplerinin, festivalin gerçekleştiği bölgeye ekonomik anlamda ne gibi etkilerinin olabileceğine yönelik görüşlerini tespit etmek amacıyla yapılmıştır. Bu amacı gerçekleştirmeye yönelik bölge olarak Mersin ilinin Silifke ilçesi seçilmiştir. Çünkü burada gerçekleştirilen Silifke Uluslararası Müzik ve Folklor festivalinin bölge turizminin gelişmesinde önemli bir etkiye sahip olduğu düşünülmektedir. Bu düşünceden hareketle bu festivalin yapıldığı bölge baz alınarak festivalin bir araç olarak ekonomik kalkınmadaki önemi ortaya konulmaya çalışılmıştır. Araştırma amacına yönelik yapılan görüşmeler sonucu elde edilen veriler içerik analizine tabi tutulmuş ve festivalin ekonomik kalkınmadaki önemine yönelik çeşitli bulgular elde edilmiştir.

Çalışmanın bulgularından hareketle öncelikle bölgenin turizm durumu değerlendirildiğinde doğal, tarihi, kültürel çekiciliklerin bölgede bulunması ve ikliminin dört mevsim turizm faaliyetlerine elverişli olması sonuçlarına ulaşılmıştır. Ancak tarım ve hayvancılık sektörünün gelişmesi, tanıtım ve hava alanı eksikliği, tesis yetersizliği gibi faktörlerin bölgenin festival turizmi açısından gelişimini olumsuz etkilediği tespit edilmiştir. Turizmin geliştirilmesi için doğal, tarihi ve kültürel varlıkların tanıtımının yapılması, çevre düzenlemeleri ve restorasyon çalışmalarının gerçekleştirilmesi, turizmi geliştirmeye yönelik sivil toplum kuruluşları ve bölgedeki turistik tesis sayısının arttırılması gerektiği düşünülmektedir.

Bölgenin festival turizmine yönelik durumu değerlendirildiğinde ise bölge halkının festivale yönelik talebinin oldukça fazla olduğu ve katılımcıların festivalden genel olarak memnun ayrıldığı sonucuna ulaşılmıştır. Katılımcılardan alınan yanıtlar doğrultusunda bölge halkının, Silifke Uluslararası Müzik ve Folklor festivalinden eğlence, şehir hayatında hareket, ekonomik getiri gibi beklentilerinin olduğu tespit edilmiştir. Festival aracıllğıyla yöreye özgü ürünlere talep artışının var olduğu ve festivalin azda olsa ekonomik kalkınmaya etki ettiği sonucuna ulaşılmıştır. Bununla birlikte festivalin bölgede iş istihdamı ve yatırım artışı yaratmadığı ayrıca bölgedeki ürünlerin fiyatında herhangi bir değişiklik oluşturmadığı gözlemlenmiştir.

Araştırma bulguları neticesinde Silifke Uluslararası Müzik ve Folklor festivaline olan talebin artması ve bölgenin ekonomik kalkınmasına katkı sağlanabilmesi adına pek çok öneri getirilebilir. Öncelikle festivale ilişkin reklam ve tanıtım faaliyetleri arttırılmalıdır. Yerel halkın festivale yönelik farkındalık düzeyi daha da artırılmalı ve bilinçlendirilmedir. Aynı zamanda ünlü sanatçıların daha çok festivale katılmaları/davet edilmeleri sağlanmalı ve festival içerisinde gerçekleşen rekreatif faaliyetlerin artırılması gerektiği düşünülmektedir. Festival etkinlikleri artırılmalı, festival içerisindeki etkinliklerde çeşitlendirilmelidir. Festival düzenleyicileri yerel 
halkın festivale yönelik düşüncelerini ölçmek amacıyla bir araştırma yapmalı ve yerel halkın beklentilerine göre festivali geliştirmelidir. Festival alanı çevresinde konaklama imkânları geliştirilmelidir. Ayrıca bölgede turistik çekicilik yaratılması ve yer verilmeli buna bağlı olarak bölgenin turistik destinasyonlarının tanıtımı sağlanmasıyla birlikte ve ekonomik kalkınmayı desteklemesi için festivalin niteliği iyileştirilmelidir. Festival Türkiye'nin 3. Büyük festivalidir (Akdeniz Haber, 2019). Yerel yöneticilerin bu durumu firsat haline dönüştürmeleri ve bölgenin ekonomik olarak kalkınmasında olumlu etkiler sağlanması için festivali daha geniş kitlelere duyurmalıdırlar. Festival kalitesini artırarak festivalin pazar payının artırılması hedeflenmelidir. Bunlara ek olarak konuyla ilgili olarak farklı örneklemlerde ya da konunun farklı boyutlarıyla ilgili çalışmalar artırılmalıdır. Ayrıca Silifke Uluslararası Müzik ve Folklor Festivali'ni konu alan ve bölgeye katkı sağlayacağı düşünülen çalışmalar yapılmalıdır. Bu sayede literatüre katkı sağlayacağı düşünülmekle birlikte bölgenin gelişimine katkı sağlanması açısından pozitif etki sağlayacağı öngörülmektedir.

\section{KAYNAKÇA}

Akdeniz Haber- http://www.akdenizhaberler.net/gundem/turkiyenin-en-buyuk-3-festivalisilifkede-coskuyla-basladi-h4802.html [Erişim Tarihi: 11.07.2019]

Akhoondnejad, A. (2016) Tourist Loyalty to a Local Cultural Event: The Case of Turkmen Handicrafts Festival. Tourism Management, 52, 468-477.

Albayrak, A. (2013). Alternatif Turizm. Ankara: Detay Yayıncllk.

Antonio Rivera, M., Hara, T., and Kock, G. (2008). Economic Impact of Cultural Events: The Case of The Zora! Festival. Journal of Heritage Tourism, 3(2), 121-137.

Arpac1, Ö. ve Orta, C. (2013) Karaman's Alternative Tourism Potential and Availability of Tourısm. Jornal of Current Researches on Social Sciences, 3, 12-24

Arslan, H. (2018). Alternatif Turizmin Bölge Ekonomisi Üzerinde Etkisi: Samsun Örneği. yayınlanmamış Yüksek Lisans Tezi, Muğla Sıtkı Koçman Üniversitesi Sosyal Bilimler Enstitüsü, Muğla

Atak, O. (2009). Türk Turizminin Tanttıminda Festivallerin Yeri ve Önemi: Antalya örneği. Yayınlanmamış Yüksek Lisans Tezi, İstanbul Üniversitesi Sosyal Bilimler Enstitüsü, İstanbul

Atalay, R. (2017). Alternatif Turizmin Bölgesel Kalkınmaya Etkisi: Beyşehir Yöresi Örneği. Yayınlanmamış Yüksek Lisans Tezi, Selçuk Üniversitesi Sosyal Bilimler Enstitüsü, Konya

Aydın, Ö. (2017). Turistlerin Sinop İlinin Alternatif Turizm Potansiyeline Yönelik Algılarının İncelenmesi. Yayınlanmamış Yüksek Lisans Tezi, İskenderun Teknik Üniversitesi Sosyal Bilimler Enstitüsü, Hatay

Bakırcı, T. G., Bucak, T. ve Turhan, K. N. (2017). Bölge Gastronomi Turizmi Üzerine Yöresel Ürün Festivallerinin Etkisi: Urla Örneği. Journal of Tourism and Gastronomy Studies, 5, 230-240.

Bako, G. A. (2016). Alternatif Turizm Kapsamında Şarap Turizmi: Kula'yı Ziyaret Eden Şarap Turistlerine Yönelik Bir İnceleme. Yayınlanmamış Yüksek Lisans Tezi, Mersin Üniversitesi Sosyal Bilimler Enstitüsü, Mersin

Bilgili, B., Yağmur, Ö. ve Yazarkan, H. (2012). Turistik Ürün Olarak Festivallerin Etkinlik ve Verimliliği Üzerine Bir Araştırma (Erzurum-Oltu Kırdağ Festivali Örneği). Uluslararası Sosyal ve Ekonomik Bilimler Dergisi, 2, 117-124. 
Chhabra, D. (2001). Heritage Tourism: An Analysis of Perceived Authenticityand Economic Impact of The Scottish Highland Games North Carolina. North Carolina State University, Raleigh

Coşkun, R., Altunışık, R. ve Yıldırım, E. (2017). Sosyal Bilimlerde Araştırma Yöntemleri SPSS Uygulamalı. Sakarya: Sakarya Yayıncılık

Cömert, M. ve Çetin, K. (2017). Gastronomi Temalı Yerel Festivaller Üzerine Bir Değerlendirme. Uluslararası Sosyal Araştırmalar Dergisi, 10, 1093-1101.

Congnong, T. (2014). The Study of Festival Tourism Development of Shanghai. International Journal of Business and Social Science, 5, 52-58.

Çoban, M. ve Süer S. (2018). Destinasyon Markalaşmasında Festival Turizminin Rolü: Alaçatı Ot Festivali Üzerine Bir Araştırma. Uluslararası Güncel Turizm Araştırmaları Dergisi, 2(1), 58-67.

Çukur, T. ve Kızılaslan, N. (2018). Milas İlçesinde Zeytin Hasat Şenliğinin Kırsal Turizme Katkısı. Turizm Ekonomi Dergisi, 3, 233-241.

Çulha, O. ve Kalkan, A. (2016). Uluslararası Zeytin Festivalinin Kalitesi ve Bölge Turizmine Katkıları: Didim Yerel Esnafı Ne Söylüyor? Journal of Tourism and Gastronomy Studies, 4, 132-164.

Cudny, W. (2013). Festival Tourism - The Concept, Key Functions and Dysfunctions in The Context of Tourism Geography Studies. Geographical Journal, 65, 105-118.

Dönmez, G. (2015). Bölgesel Kalkınma Çerçevesinde Termal Turizm Faaliyetlerinin Yerel Halk Üzerindeki Etkileri: Mudurnu Örneği. Yayınlanmamış Yüksek Lisans Tezi, Düzce Üniversitesi Sosyal Bilimler Enstitüsü, Düzce

Ekin, Y. (2011). Etkinlik Turizmi Kapsammda Festivaller ve Antalya Altın Portakal Film Festivalinin Yerel Halk Üzerindeki Sosyal Etkileri Konulu Bir Araştırma. Yayınlanmamış Yüksek Lisans Tezi, Akdeniz Üniversitesi Sosyal Bilimler Enstitüsü, Antalya

Ercan, H. F. (2018). Sanat Etkinlikleri Bağlamında Festivallerin Kentsel ve Toplumsal Gelişime Katkıları: Kervansaray Buluşması. İnönü Üniversitesi Uluslararası Sosyal Bilimler Dergisi, 7, 72-87.

Erdem, Ö. ve Mızrak, M. (2017). Festivallerin Bölge Turizmine Katkıları ve Sürdürülebilirliği: Uluslararası Mengen Aşçlık ve Turizm Festivali Örneği. International Sustainable Tourism Congress, 100

Giritlioğlu, İ., Olcay, A. ve Özekici, Y.K. (2015). Bir Turizm Çeşitliliği Olarak Festival Etkinliklerinin Sınıflandırılması: Türkiye Üzerine Bir Değerlendirme. Odü Sosyal Bilimler Araştırmaları Dergisi (odüsobiad), 5(13), 306-323.

Gül, K., Erdem, B. ve Gül, M. (2013). Yerel Festivallerin Etkinliğine Bağlı Ziyaretçi Kazanımları: Sındırgı Yağcıbedir Festivali Örneği. Süleyman Demirel Üniversitesi İktisadi ve İdari Bilimler Fakültesi Dergisi, 18(2), 213-239.

Güner, K. (2018). Turizm Sektörünün Bölgesel Kalkımma Üzerine Etkisi: Giresun Örneği. Yayınlanmamış Yüksek Lisans Tezi, Ordu Üniversitesi Sosyal Bilimler Enstitüsü, Ordu

Karaca, O. B., Yıldırım, O. ve Çakıcı, A. C. (2017). Adana Uluslararası Portakal Çiçeği Karnavalına Katılan Ziyaretçilerin Algı ve Memnuniyetleri. Mustafa Kemal Üniversitesi Sosyal Bilimler Enstitüsü Dergisi, 14, 222-239.

Karagöz, D. (2006). Etkinlik Turizmi ve Etkinlik Turizmi Bağlamında Yabancı Ziyaretçi Harcamalarının Ekonomiye Etkisi: Formula 12005 Türkiye Grand Prix Örneği. Yayınlanmamış Yüksek Lisans Tezi, Anadolu Üniversitesi Sosyal Bilimler Enstitüsü, Eskişehir 
Kargiglioğlu, Ş. ve Kabacık, M. (2017). Gastronomi Turizmi Kapsamında Urla Enginar Festivaline Gelen Turistlerin Festival Hakkındaki Görüşleri. Journal of Tourism and Gastronomy Studies, 5, 409421.

Keskin, A. (2016). Yerel Kalkınmada Yerel Yönetimlerin Rolü: Turizm Örneği. Atatürk Üniversitesi İktisadi ve İdari Bilimler Dergisi, 30, 143-154.

Kılıçlığlu, İ. (2018). Yerel Kalkınmada Turizm Sektörünün Rolü ve Bartın İli Örneği. Yayınlanmamış Yüksek Lisans Tezi, Karamanoğlu Mehmetbey Üniversitesi Sosyal Bilimler Enstitüsü, Karaman

Kömürcü, G. B. (2013). Etkinlik Turizmi Çeşidi Olarak Festivaller: Bozcaada Yerel Tatlar Festivali Örneği. Yayınlanmamış Yüksek Lisans Tezi, Çanakkale Onsekiz Mart Üniversitesi Sosyal Bilimler Enstitüsü, Çanakkale

Kömürcü, S., Sarıbaş, Ö. ve Akbaba, A. (2017). Yerel Kültürel Festivallerde Katılımcı Deneyimleri: Manisa Mesir Macunu Festivali Örneği. VII. Ulusal III. Uluslararası Doğu Akdeniz Turizm Sempozyumu Bildiriler Kitabı, 88-99.

Küçük, M. (2015). Turizmin Yerel Kalkınmaya Etkisi: Ankara Kızllcahamam Örneği. Yayınlanmamış Yüksek Lisans Tezi, Atılım Üniversitesi Sosyal Bilimler Enstitüsü, Ankara

Litvin, S. W. and Fetter, E. (2006). Can A Festival Be Too Successful? A Review of Spoleto, USA. International Journal of Contemporary Hospitality Management, 18, 41-49.

Mısırlı, İ. ve Özdemir, H. (2018). Festivallerin Yerel Halk Üzerindeki Sosyal Etkileri Üzerine Bir Araştırma: Ilgaz Dağı. Journal of Tourism and Gastronomy Studies, 6, 419- 435.

Özer, E. Z. ve Çavuşoğlu F. (2014). Rekreasyonel Bir Faaliyet Olarak Yerel Etkinliklerin Kırsal Turizme Etkisi. International Journal of Science Culture and Sport, 2, 191-202.

Özgürel, G., Ruhan, A. ve Bingöl, Z. (2015). Yerel Kalkınmada Bir Araç Olarak Festivaller: Munzur Kültür ve Doğa Festivali. Uluslararası Sosyal ve Ekonomik Bilimler Dergisi, 2, 113-121.

Özkan, E., Curkan, S. C., ve Sarak, E. C. (2015). Festivallerin Katılan Ziyaretçiler Üzerine Etkileri: Alaçatı Ot Festivali Örneği. Gümüşhane Üniversitesi Sosyal Bilimler Enstitüsü Elektronik Dergisi, 6, 59-69.

Rivara M. A., Hara, T. and Kock, G. (2008). Economic Impact of Cultural Events: The Case of The Zora! Festival. Journal of Heritage Tourism, 3, 121-137.

Saatçi, G. ve Yalçınkaya, T. Yöresel Festivallerin Yerel Halk Üzerindeki Etkileri: Alaçatı Ot Festivali. Sosyal Bilimler Enstitüsü Dergisi, 153-170.

Saçılık, M. Y. ve Çevik, S. (2017). Etkinlik Turizminin Sağladığı Faydalar Açısından “Erdek Zamanı Festivali" Katılımclarının Memnuniyet Düzeylerinin Belirlenmesi. Route Educational and Social Science Journal, 4, 240-257.

Sert, A. N. (2013). Kırsal Turizm Bölgelerinde Festivallerin Yerel Halk Üzerindeki Sosyal Etkileri: Beypazarı Festivaline Yönelik Bir Araştırma. Yayınlanmamış Yüksek Lisans Tezi, Anadolu Üniversitesi Sosyal Bilimler Enstitüsü, Eskişehir

Sullivan, D. O. ve Jackson, M. J. (2002). Festival Tourism: A Contributor to Sustainable Local Economic Development? Journal of Sustainable Tourism, 10, 325-342.

Şengel, Ü. (2015). Bitlis İlinin Kalkınmasında Turizmin Rolü: Yerel Paydaşlar Üzerine Bir Araştırma. Yayınlanmamış Yüksek Lisans Tezi, Sakarya Üniversitesi Sosyal Bilimler Enstitüsü, Sakarya 
Şengül, S. ve Genç, K. (2016). Festival Turizmi Kapsamında Yöresel Mutfak Kültürünün Destekleyici Ürün Olarak Kullanılması: Mudurnu İpekyolu Kültür Sanat ve Turizm Festivali Örneği. Pamukkale Üniversitesi Sosyal Bilimler Enstitüsü, 23, 79-89.

Tanford, S. and Jung, S. (2017). Festival Attributes and Perceptions: A Meta-analysis of Relationships with Satisfaction and Loyalty. Tourism Management, 61, 209-220.

Taştan, H., Soylu, A. G .ve Demir, Ş. (2018). Adana Lezzet Festivaline Katılan Bireylerin Festival Algılarının Belirlenmesi. The Journal of Academic Social Science, 6, 334-349.

Tayfun, A. ve Arslan, E. (2013). Festival Turizmi Kapsamında Yerli Turistlerin Ankara Alışveriş Festivali'nden Memnuniyetleri Üzerine Bir Araştırma. İşletme Araştırmaları Dergisi, 5, 191-206.

Türk

Dil

Kurumu-

http://www.tdk.gov.tr/index.php?option=com_gts\&kelime=FEST\%C4\%B0VAL [Erişim Tarihi: 29.03.2019].

TÜRSAB-https://www.tursab.org.tr/istatistikler/turizmin-ekonomideki-yeri

[Erişim Tarihi:20.03.2019].

Ünlüölen, K., Tayfun, A. ve Kılıçlar, A. (2011). Turizm Ekonomisi (3. Bask1). Ankara: Nobel Akademik Yayıncilık

Visser, G. (2005). Let's Be Festive: Exploratory Notes on Festival Tourism in South Africa. Urban Forum, 6, 155-175.

Yayla, Ş. (2017). Yöresel Yemek Festivaline Katılım Motivasyonu ile Festivallerin Destinasyon Imajına ve Davranışsal Niyetlere Etkisi. Yayınlanmamış Yüksek Lisans Tezi, Eskişehir Osmangazi Üniversitesi Sosyal Bilimler Enstitüsü, Eskişehir

Yemenoğlu, E., Dalgın, T. ve Çeken, H. (2013). Geleneksel Festivallerin Kırsal Turizm Üzerindeki Etkiler: Denizli-Honaz Kiraz Festivali Örneği. Uluslararası Sosyal ve Ekonomik Bilimler Dergisi, 1, $16-21$.

Yıldırım, A. ve Şimşek, H. (2016). Sosyal Bilimlerde Nitel Araştırma Yöntemleri. Ankara: Seçkin Yayıncilik

Yıldız, G. (2014). Rekreasyon Araştırmaları İçin Temel Bir Değişsenin Kavramsal ve Operasyonel Tanımlarıla Sunumu ve Geleneksel Ön Kabullere Yönelik Eleştirel Sınamalar. Yayınlanmamış Yüksek Lisans Tezi, Mersin Üniversitesi Sosyal Bilimler Enstitüsü, Mersin

Yıldız, S. B. ve Polat, E. (2016). Yerel Halkın Eskişehir'de Düzenlenen Festivallerin Etkilerine Yönelik Algiları. Journal of Tourism and Gastronomy Studies, 4, 40-62.

Yolal, M., Gursoy, D., Uysal, M., Kim, H. and Karacaoğlu S. (2016). Impacts of Festivals and Events on Residents' Well-Being. Annals of Tourism Research, 61, 1-18

Yüksek, T., Cengız, T. ve Yüksek, F. (2008). Doğal Alanlarda Festival Etkinliklerinin KorumaKullanma Açısından Değerlendirilmesi: Kafkasör Kültür, Sanat ve Turizm Festivali Örneği. Ekoloji Dergisi, 17, 37-45.

Quinn, B. (2005). Arts Festivals and the City. Urban Studies, 42, 927-943. 